\title{
Article 5. Fair and Equitable Benefit-sharing
}

1. In accordance with Article 15, paragraphs 3 and 7 of the Convention, benefits arising from the utilization of genetic resources as well as subsequent applications and commercialization shall be shared in a fair and equitable way with the Party providing such resources that is the country of origin of such resources or a Party that has acquired the genetic resources in accordance with the Convention. Such sharing shall be upon mutually agreed terms.

2. Each Party shall take legislative, administrative or policy measures, as appropriate, with the aim of ensuring that benefits arising from the utilization of genetic resources that are held by indigenous and local communities, in accordance with domestic legislation regarding the established rights of these indigenous and local communities over these genetic resources, are shared in a fair and equitable way with the communities concerned, based on mutually agreed terms.

3. To implement paragraph 1 above, each Party shall take legislative, administrative or policy measures, as appropriate.

4. Benefits may include monetary and non-monetary benefits, including but not limited to those listed in the Annex.

5. Each Party shall take legislative, administrative or policy measures as appropriate, in order that the benefits arising from the utilization of traditional knowledge associated with genetic resources are shared in a fair and equitable way with indigenous and local communities holding such knowledge. Such sharing shall be upon mutually agreed terms.

\section{Annex. Monetary and Non-monetary Benefits}

1. Monetary benefits may include, but not be limited to:

(a) Access fees/fee per sample collected or otherwise acquired;

(b) Up-front payments;

(c) Milestone payments;

(d) Payment of royalties;

(e) Licence fees in case of commercialization;

(f) Special fees to be paid to trust funds supporting conservation and sustainable use of biodiversity;

(g) Salaries and preferential terms where mutually agreed; 

(h) Research funding;
(i) Joint ventures;
(j) Joint ownership of relevant intellectual property rights.

2. Non-monetary benefits may include, but not be limited to:

(a) Sharing of research and development results;

(b) Collaboration, cooperation and contribution in scientific research and development programmes, particularly biotechnological research activities, where possible in the Party providing genetic resources;

(c) Participation in product development;

(d) Collaboration, cooperation and contribution in education and training;

(e) Admittance to ex situ facilities of genetic resources and to databases;

(f) Transfer to the provider of the genetic resources of knowledge and technology under fair and most favourable terms, including on concessional and preferential terms where agreed, in particular, knowledge and technology that make use of genetic resources, including biotechnology, or that are relevant to the conservation and sustainable utilization of biological diversity;

(g) Strengthening capacities for technology transfer;

(h) Institutional capacity-building;

(i) Human and material resources to strengthen the capacities for the administration and enforcement of access regulations;

(j) Training related to genetic resources with the full participation of countries providing genetic resources, and where possible, in such countries;

(k) Access to scientific information relevant to conservation and sustainable use of biological diversity, including biological inventories and taxonomic studies;

(l) Contributions to the local economy;

(m) Research directed towards priority needs, such as health and food security, taking into account domestic uses of genetic resources in the Party providing genetic resources;

(n) Institutional and professional relationships that can arise from an access and benefit-sharing agreement and subsequent collaborative activities;

(o) Food and livelihood security benefits;

(p) Social recognition;

(q) Joint ownership of relevant intellectual property rights. 
This Article includes three inter-related obligations for State Parties: 1) an inter-State obligation to share benefits, ${ }^{1} 2$ ) an obligation to share benefits with indigenous and local communities when benefits derive from genetic resources held by these communities; ${ }^{2}$ and 3 ) an obligation to share benefits arising from the utilization of traditional knowledge with indigenous and local communities holding such knowledge. ${ }^{3}$ All these obligations (with slightly different wording) are to be fulfilled by the enactment of national legislative, administrative or policy measures. In all these cases, benefits may be monetary and non-monetary, as exemplified in the Annex to the Protocol, which is also discussed here in conjunction with Article 5.

Article 5 largely ${ }^{4}$ reproduces the content of свD Articles 15(7) and 15(3). The indicative list of monetary and non-monetary benefits annexed ${ }^{5}$ to the Protocol furthermore reproduces the list in Appendix II of the Bonn Guidelines almost verbatim. ${ }^{6}$ However, the Protocol breaks new ground by: i) using more forceful language with respect to benefit-sharing from genetic resources; ${ }^{7}$ ii) addressing for the first time questions related to benefit-sharing with indigenous and local communities when genetic resources are held by these communities; and iii) addressing benefit-sharing from the use of their traditional knowledge for the first time in as far as it is 'associated with genetic resources.'

1 Nagoya Protocol Article 5(1) and (3).

2 Nagoya Protocol Article 5(2).

3 Nagoya Protocol Article 5(5). See cвD Working Group on Article 8(j), "How Tasks 7, 10 and 12 could best contribute," UNEP/CBD/WG8J/8/4/Rev.2, paragraph 14 and СвD Working Group on ABs, "Vienna Workshop on Matters related to Traditional Knowledge Associated with Genetic Resources and the International Regime on Access and Benefit-sharing" (18 March 2009) Un Doc UNEP/CBD/WG-ABS/7/INF/7.

4 Particularly Nagoya Protocol Article 5(1) and 5(3).

5 Note that the Annex to the Protocol was not negotiated by СвD Parties, and was introduced as Co-Chairs' text following the Cali meeting: Cali Draft, draft annex I.

6 Besides minor editorial differences (the term 'provider Party/country'), the only substantive difference between the list of benefits in the Bonn Guidelines and the Nagoya Protocol is section $2(\mathrm{~g})$ in relation to strengthening capacity for technology transfer. This divergence has also resulted in the deletion of a reference to indigenous and local communities.

7 The Nagoya Protocol decidedly indicates that benefits from genetic resources 'shall be shared,' whereas the свр Article 15(7) used the more qualified expression 'Each Contracting Party shall take legislative, administrative or policy measures ... with the aim of sharing in a fair and equitable way the... benefits arising from the commercial and other utilization of genetic resources...' (emphasis added). 
Albeit heavily qualified, the obligations contained in Articles 5(2) and 5(5) are major developments in international environmental law. First, while not phrased in human rights terms, they nevertheless address an internal situation between a State and its communities, which is usually the object of human rights treaties. ${ }^{8}$ Second, the obligations appear underpinned not only by purely procedural environmental rights, ${ }^{9}$ but also substantive environmental rights, ${ }^{10}$ as will be discussed below.

The following sections will first identify the innovations of this provision vis-à-vis the text of the $\mathrm{CBD}$, and then discuss in more detail the content of the three inter-related obligations established by Article 5, in turn. A reflection will then be offered on the role of mutually agreed terms in the architecture of the Protocol, and on the usefulness of contemplating both monetary and nonmonetary benefits in ABS transactions.

8 On the debate on environmental human rights, see Human Rights Council, "Human rights and the environment” (12 April 2011) UN Doc A/HrC/Res/16/11; Human Rights Council, "Report of the Independent Expert John H. Knox," A/HRC/22/43; F. Francioni, 'International Human Rights in an Environmental Horizon', European Journal of International Law 21 (2010): 41; Alan Boyle, "Human Rights or Environmental Rights? A Reassessment," Fordham Environmental Law Review 18 (2007): 471; and Alan Boyle, "Human Rights and the Environment: Where Next?," European Journal of International Law 23 (2012): 1.

9 See Introduction to this commentary, section 4.3. Human Rights Council, "Report of the Independent Expert John H. Knox," A/HRC/22/43, paragraph 7, also discusses the distinction between procedural and substantive rights, paragraphs 40-43.

10 Compare with recognition of certain substantive environmental rights in few regional human rights treaties and human rights case law as discussed in Shelton, "Human Rights and the Environment," op. cit. Compare also with the international obligations related to purely procedural environmental rights that can be found in the Convention on Access to Information, Public Participation in Decision-making and Access to Justice in Environmental Matters (Aarhus, 25 June 1998, in force 30 October 2001) 2161 unTs 447 (hereinafter, Aarhus Convention). Although the Aarhus Convention makes reference to a substantive right to a healthy environment in an operative provision (Article 1), such a right is only referred to as a rationale for guaranteeing procedural environmental rights, which constitute the core of the Convention. E.g., Declaration of the United Kingdom of Great Britain and Northern Ireland, in "Convention on Access to Information, Public Participation in Decision-making and Access to Justice in Environmental Matters," UN Treaty System, accessed 30 November 2013, <http://treaties.un.org/Pages/ViewDetails. aspx?src=TREATY\&mtdsg_no=XXVII-13\&chapter=27\&lang=en $>$. 

Resources

Article 5(1) establishes an inter-State obligation to share benefits arising from the utilization of genetic resources but also from 'subsequent applications and commercialization' with the Party providing such resources. It thus strengthens the legal obligation already existing under CBD Article 15, which is expressly recalled, and confirms that benefit-sharing can arise both from 'commercial' and other utilization of genetic resources. The reference to 'subsequent applications and commercialization' - an expression that is not defined in the Protocol - attempts to address practical difficulties in separating different phases of the research and development chain. The reference thus underlines that inter-State benefit-sharing is to be understood broadly, based on the expectation that benefits that must be shared might arise during all the phases after a genetic resource was accessed. Necessary details about benefit-sharing arising from subsequent applications and commercialization will likely be provided in domestic ABS frameworks and possibly guidance may be provided by the Protocol's governing body in the future. ${ }^{11}$

In a regular scenario, the general, inter-State benefit-sharing obligation is specified at the time of access, when PIC is obtained and MAT are established. ${ }^{12}$ In this scenario, the Protocol envisages that the permit, which is the basis for the internationally recognized certificate of compliance, ${ }^{13}$ is to be issued 'at the time of access.' Frequently, however, it is during the utilisation of a genetic resource, rather than at the time of access, that its actual or potential value becomes evident and more easily verifiable. ${ }^{14}$ So the time of access will often be too early to conclusively determine what is fair and equitable benefit-sharing. ${ }^{15}$ For this reason, СвD Article 15 has been interpreted as prescribing two MATrelated obligations: the establishment of MAT at the time of access, and the re-establishment or reopening of MAT with regard to benefit-sharing at a later stage, in which further or different information on utilization becomes available. As a result, although MAT are normally established upon access (and can possibly be (re)negotiated at a later stage), ${ }^{16}$ there may be situations in which

\footnotetext{
11 Nagoya Protocol Article 26(4)(a). See this commentary on Article 26, section 2.

12 In accordance with Nagoya Protocol Articles 6-7: see this commentary on Article 6, sections 3-4, and on Article 7, section 2.

13 Nagoya Protocol Articles 6(3)(e) and 17(2). See this commentary on Article 17, section 3.

14 Tvedt, “Beyond Nagoya," op. cit., 160.

15 Ibid., 163.

16 See Introduction to this commentary, Section 1.3.
} 
negotiations and establishment of MAT on access and on benefit-sharing can occur at different points in time. ${ }^{17}$ This is why the PIC decision and the initial MAT would oblige users to renegotiate the terms of utilisation and benefitsharing in case for instance of changes in the understanding of the resource's value, change of the user's intent (e.g., from non-commercial to commercial), or change of the agreed type of utilization. ${ }^{18}$

In all events, access to genetic resources without PIC and/or MAT in the logic of the Convention and the Protocol should not deprive States and/or indigenous and local communities of their right to benefit-sharing. Article 5(1) links the benefit-sharing obligation to the definition of 'utilization of genetic resources,' which is provided by the Protocol, ${ }^{19}$ and which does not mention 'access' to the resources. On that basis, an argument can be made that benefit-sharing requirements may not necessarily be connected with access procedures, as utilization can take place long after the acquisition of genetic resources and involve other countries or private parties. ${ }^{20}$ An alternative interpretation would point to Article 6(1), which refers to 'access to genetic resources for their utilization,' thereby arguably suggesting a sequence and direct temporal link between access for, and benefit-sharing from, utilisation. Such interpretation would tend to emphasize that the realization of the benefitsharing obligation rests on the Protocol provisions on compliance, which in turn rely on the existence of a domestic ABs framework.

As anticipated, the benefit-sharing obligation presupposes a bilateral relationship between States, with benefits flowing to a 'Party providing such resources that is the country of origin of such resources or the Party that has acquired genetic resources in accordance with the Convention.' This mirrors language found in СвD Article 15(3). The reference to 'genetic resources acquired in accordance with the Convention' points to a country that, with the consent of the country of origin, facilitated access to those resources and is entitled to receive a share of benefits arising from their utilization. ${ }^{21}$ The opposite situation (i.e., genetic resources acquired not in accordance with the Convention) may point to two distinct cases: resources acquired prior to the Convention's entry into force, and resources acquired from the country

17 Tvedt and Young, Beyond Access, op. cit., 71; and Tvedt, “Beyond Nagoya," op. cit., 172. See Introduction to this commentary, section 1.3.

18 As anticipated in Nagoya Protocol Articles 6(3)(g) and 8(a).

19 Nagoya Protocol Article 2(c). See this commentary on Article 2, section 2.

20 Greiber et al., Explanatory Guide, op. cit., 84-85.

21 Tvedt and Young, Beyond Access, op. cit., 14. 
of origin without PIC and MAT after the Convention's entry into force. ${ }^{22}$ The first case is linked to the question of temporal scope, which has already been discussed. ${ }^{23}$ In the second case, those countries that have acquired resources without PIC and MAT from the country of origin after the Convention's entry into force will have no rights under the Protocol. In other words, they are in violation of the Convention and are not entitled to benefit-sharing in case of further transfer of the resources originally acquired without PIC and MAT. ${ }^{24}$

The benefit-sharing obligation in Article 5(1) does not identify specific addressees (it uses an indeterminate passive form 'benefit-sharing... shall be shared'). This can be explained by the understanding that in practice benefits will be most likely obtained from private parties, such as research institutions and biotech companies, who utilize genetic resources. For this reason, the Protocol establishes that benefit-sharing shall be upon MAT, ${ }^{25}$ as MAT is likely the most effective way to guide the implementation of Article 5(1). In the light of this, the related obligation for States as spelt out in Article 5(3) is to take legislative, administrative or policy measures, as appropriate, to create obligations for private users under their jurisdiction to share benefits, so as to implement the corresponding international benefit-sharing obligations. ${ }^{26}$

Article 5(1) leaves a broad range of implementing measures (by reference to 'legislative, administrative or policy measures') to the discretion of its Parties, and does not attempt to establish any guidance on how to address questions of fairness and equity in domestic ABs frameworks. ${ }^{27}$ Nevertheless, it can be argued that these measures should be able to contribute to legal certainty in ABS transactions, the importance of which is emphasized in the Protocol preamble. ${ }^{28}$ In addition, it should be stressed that the qualifier 'as appropriate',

22 Glowka, Burhenne-Guilmin and Synge, Guide to the Convention on Biological Diversity, op. cit., 77.

23 See this commentary on Article 3, section 3.1.

24 Glowka, Burhenne-Guilmin and Synge, Guide to the Convention on Biological Diversity, op. cit., 79.

25 As is explicitly foreseen in the last sentence of Nagoya Protocol Article 5(1).

26 Greiber et al., Explanatory Guide, op. cit., 84.

27 Compare with Nagoya Protocol Article 6(3)(a-b); see this commentary on Article 6, section 5. In practical terms, such measures may be taken in the context of access in provider jurisdictions or in the context of utilisation activities in user jurisdictions. In the former case, Parties should consider whether to move beyond the minimum access requirements set out in Article 6. In the latter case, Parties must be mindful of their overarching benefitsharing obligation when implementing their obligations related to compliance (Nagoya Protocol Articles 15, 16 and 18).

28 Nagoya Protocol 9th preambular recital. 
while emphasizing the margin of appreciation of States in choosing how to implement this provision, does not call into question whether States are to perform their obligation at all. ${ }^{29}$ Ultimately the good-faith implementation of this provision may be judged against the objective of the Protocol on realizing fair and equitable benefit-sharing among and within States. ${ }^{30}$

\section{Intra-State Benefit-sharing from the Utilization of Genetic Resources Held by Indigenous and Local Communities}

While the wording of Article 5(2) is largely similar to СвD Article 15(7), it is worth underlining the fundamental conceptual difference between the two provisions. Article 5(2) does not deal with 'inter-State' benefit-sharing, but with an internal situation: it creates an obligation for each Party to share benefits with indigenous and local communities (non-State actors) 'holding' genetic resources.

Article 5(2) arguably presupposes that each Party identifies indigenous and local communities (for the purposes of implementing the Protocol) ${ }^{31}$ in its territory in order to clarify whether these (or some of these) communities 'hold' genetic resources. For these Parties the provision sets out an obligation to create measures to 'channel' resulting benefits to the communities concerned. Similarly to the general obligations to share benefits in Article 5(1), ultimately the terms of benefit-sharing for indigenous and local communities will be spelt out in MAT, ${ }^{32}$ as most likely private parties will actually do the sharing of benefits.

The groundbreaking nature of Article 5(2) should be highlighted from the outset: for the first time in international environmental law, a treaty creates an obligation for States to establish measures to reward indigenous and local communities responsible for the stewardship of genetic resources and their resulting contribution to scientific progress for the benefit of the global community. Article 5(2) in fact goes significantly beyond the letter of the $\mathrm{CBD},{ }^{33}$

\footnotetext{
29 Introduction to this commentary, section 5, fn. 225.

$30 \quad$ See this commentary on Article 1.

31 As discussed in section 3.2 below, the identification of indigenous peoples and local communities may not be a straightforward matter, also in the absence of an international definition of either term or international consensus on the difference between the two terms: Savaresi, “International Human Rights Law Implications," op. cit., 73-74.

32 Final part of Nagoya Protocol Article 5(2).

33 свD Articles 15 and 8(j).
} 
and the Protocol's own negotiating mandate, ${ }^{34}$ as neither mentions communities' rights over genetic resources, nor refers to indigenous and local communities as recipients of a share of the benefits arising from the utilization of genetic resources held by them. ${ }^{35}$

From a broader international law perspective, this provision can be possibly interpreted as implicitly underpinned by a substantive environmental right ${ }^{36}$ of indigenous and local communities to their genetic resources. ${ }^{37}$ It embodies an obligation owed directly to them, ${ }^{38}$ deriving from established international human rights, in their collective dimension, ${ }^{39}$ to indigenous peoples' selfdetermination, ownership and cultural identity. ${ }^{40}$ In comparison, UNDRIP only includes genetic resources in a list of manifestations of indigenous

34 As set out in CBD Decision 7/19, section D.

35 Свр Working Group on Article 8(j), "How Tasks 7, 10 and 12 could best contribute," UNEP/ СвD/WG 8J/8/4/Rev.2, 14 .

36 On the lack of substantive environmental rights in international law, except for the African context: Rhona K.M. Smith, Textbook on International Human Rights, 5th ed (Oxford: Oxford University Press, 2012), 390-1; Boyle, "Human Rights and the Environment," op. cit., 29-30; and Malgosia Fitzmaurice, "Environmental Degradation," in International Human Rights Law, ed. Daniel Moeckli, Sangeeta Shah and Sandesh Sivakumaran (Oxford: Oxford University Press, 2010), 622, 622.

37 Compare with ITPGRFA Article 9, that although titled 'farmers' rights', only contains a hortatory provision for States to enact supportive legislation; and the Aarhus Convention, that only focuses on procedural environmental rights.

38 International human rights can be identified in 'obligations [that] are owed directly to individuals (and not to the national government of an individual)': Rosalyn Higgins, Problems and Process: International Law and How We Use It (Oxford: Oxford University Press, 1994) 94.

39 On the 'communitarization' of indigenous peoples' rights, see Alessandro Fodella, "International Law and the Diversity of Indigenous Peoples," Vermont Law Review 30 (2001): 565; Wiessner, "The Cultural Rights of Indigenous Peoples," op. cit.; Human Rights Committee, "General Comment No. 31: Nature of the general legal obligations on State Parties to the Covenant" (26 May 2004) un Doc CCPR/C/21/Rev.1/Add.13, paragraph 9, which reads: 'The beneficiaries of the rights recognized by the Covenant are individuals. Although, with the exception of article 1, the Covenant does not mention the rights of legal persons or similar entities or collectivities, many of the rights recognized by the Covenant ... may be enjoyed in community with others...'

40 Human Rights Council, "Report of the Special Rapporteur on indigenous peoples' rights" A/HrC/9/9, paragraph 40. See also UndRIP, Article 1, which reads: 'Indigenous peoples have the right to the full enjoyment, as a collective or as individuals, of all human rights and fundamental freedoms as recognized in the Charter of the United Nations, the Universal Declaration of Human Rights and international human rights law.' We are grateful to Annalisa Savaresi for drawing our attention to this point. 
sciences, technologies and cultures, ${ }^{41}$ and otherwise generally refers to indigenous peoples' right to manage their natural resources, ${ }^{42}$ their right to maintain and strengthen their distinctive spiritual relationship with their traditionally owned resources, ${ }^{43}$ and the right to own, use, develop and control the resources that they possess by reason of traditional ownership or use. ${ }^{44}$ In that respect, the Nagoya Protocol implicitly confirms and clarifies that the above-cited UNDRIP provisions apply to the specific case of genetic resources. ${ }^{45}$

In addition, UNDRIP generally calls upon States, in conjunction with indigenous peoples, to take effective measures to recognize and protect the exercise of their right to maintain, control, protect and develop the manifestations of their culture, including genetic resources, ${ }^{46}$ and to create effective mechanisms of preventing and redressing dispossession of their resources. ${ }^{47}$ UNDRIP then only foresees a right of redress for indigenous peoples' resources that they have traditionally owned or otherwise used, and which have been confiscated, taken, used or damaged without their PIC. ${ }^{48}$ The Nagoya Protocol, instead, goes beyond UNDRIP by encapsulating, in a legally binding provision, a benefitsharing obligation owed directly to ${ }^{49}$ indigenous and local communities. This

41 UNDRIP Article 31(1), which reads: 'Indigenous peoples have the right to maintain, control, protect and develop their cultural heritage, traditional knowledge and traditional cultural expressions, as well as the manifestations of their sciences, technologies and cultures, including human and genetic resources, seeds, medicines, knowledge of the properties of fauna and flora, oral traditions, literatures, designs, sports and traditional games and visual and performing arts. They also have the right to maintain, control, protect and develop their intellectual property over such cultural heritage, traditional knowledge, and traditional cultural expressions.'

43 UNDRIP Article 25.

44 UNDRIP Article 26(2).

45 The argument that indigenous peoples' rights over their resources also encompass their rights to their 'genetic' resources had been put forward by Lenzerini, "Indigenous Peoples' Cultural Rights," op. cit., 140, on the basis of un Commission on Human Rights, "Final report of the Special Rapporteur on indigenous peoples' permanent sovereignty over natural resources" (12 July 2004) Un Doc E/CN.4/Sub.2/2004/30/Add.1, paragraph 11 and the inextricable link between genetic resources and traditional knowledge as 'two inseparable elements of a unique social (and legal) concept that expresses the spiritual relationship of indigenous groups to their natural resources.' See also Nagoya Protocol 22nd preambular recital.

46 UNDRIP Article 31(2).

47 UNDRIP Article 8(2)(b).

48 UNDRIP 28(1).

49 Paraphrasing Higgins, Problems and Process, op. cit., 94 (see quote at fn. 38 above). 
obligation arises specifically from the use of genetic resources held by them, ${ }^{50}$ even in the absence of any restriction or deprivation of their right to use their genetic resources ${ }^{51}$ that may result from an ABS transaction (that is, when they have exercised their right to PIC). The Nagoya Protocol also goes beyond existing human rights instruments by identifying as beneficiaries of such entitlement not only indigenous peoples, but also local communities. ${ }^{52}$

Nonetheless, Article 5(2) is heavily qualified. The following subsections will thus first offer an interpretation of the obligation in the light of relevant international human rights standards, and then discuss questions arising from the qualifications in Article 5(2), focusing on the lack of a definition of 'indigenous and local communities' as right-holders under the Protocol, and the references to 'accordance with domestic legislation regarding established rights.'

\subsection{States'Obligation}

Article 5(2) sets out an obligation for Parties to adopt (or, implicitly, to revise) domestic measures ensuring the fair and equitable sharing of benefits arising from the utilization of genetic resources held by indigenous and local communities. The modalities of such an internal mechanism will be dependent on the modalities of the exercise of these communities' rights over genetic resources in a given Party, which will likely vary from one domestic legal framework to another.

In light of international human rights standards, Parties are to discharge this obligation with the participation of the communities concerned. UNDRIP, for instance, calls upon States to consult and cooperate in good faith with the indigenous peoples concerned through their own representative institutions in order to obtain their PIC ${ }^{53}$ before adopting legislative or administrative measures that may affect them: ${ }^{54}$ clearly domestic measures on benefit-sharing fall

5o Note that the ILo Convention No. 169 Article 15(2) provides more timidly that indigenous peoples shall wherever possible participate in the benefits of exploration or exploitation of 'resources pertaining to lands' (emphasis added).

51 Compare with the understanding of benefit-sharing as 'compensation' in Case of the Saramaka People v. Suriname, Interpretation of the Judgment of Preliminary Objections, Merits, Reparations, and Costs, Judgment, Case No. 12,338 (IACtHR, 12 August 2008), paragraph 140 (hereinafter, Saramaka People v. Suriname 2008).

For a preliminary discussion on the possible legal arguments on the status of the human rights of local communities, see Introduction to this commentary, section 4.2.

53 See further discussion on community PIC in this commentary on Article 6, section 4.2 and on Article 7, section 2.

54 UNDRIP Articles 19 and 32(2); ILO Convention No. 169, Article 6(2). See also Human Rights Council, "Report of the Special Rapporteur on indigenous peoples' rights," A/HRC/24/41, 
into this category. Consultations should be carried out through the establishment and implementation, in conjunction with indigenous peoples concerned, of a fair, independent, impartial, open and transparent process, recognizing the right of indigenous peoples to participate in such process and giving due recognition to indigenous peoples' laws, ${ }^{55}$ traditions, customs and land tenure systems, in order to recognize and adjudicate the rights of indigenous peoples pertaining to their lands, territories and resources, including those which were traditionally owned or otherwise occupied or used. ${ }^{56}$ Implementation of domestic ABs frameworks, then, should be based on States' obligation to consult and cooperate in good faith with the indigenous peoples concerned through their own representative institutions in order to obtain their PIC. ${ }^{57}$

In addition, national measures should not diminish or extinguish existing rights of indigenous peoples. ${ }^{58}$ Taking note of relevant provisions of UND RIP, ${ }^{59}$ these rights include the right of indigenous peoples to maintain, control, protect and develop manifestations of their sciences, technologies and cultures, including genetic resources, seeds, medicines, and knowledge of the properties of fauna and flora. ${ }^{60}$ This specifically includes the right to their traditional medicines and to maintain their health practices, including the conservation of their vital medicinal plants, animals and minerals. ${ }^{61}$ UNDRIP also calls for just and fair redress if indigenous peoples are deprived of their means of subsistence and development, ${ }^{62}$ which may well include genetic resources obtained without their PIC.

paragraphs 19-25; Sarayaku v. Ecuador, paragraph 165: 'there is currently a clearly recognized right to consultation based on developments within the Inter-American system on the property rights of indigenous peoples, other international instruments, and case-law of the highest domestic courts in the Americas.'; and note that '[i]t appears that through the process evolved from the drafting and adoption of UNDRIP and the creation of UNPFII that there is now a principle backed by supporting State practice that rights of indigenous peoples cannot be determined without their participation and consent:' Boyle and Chinkin, Making of International Law, op. cit., 50.

55 Note that this is also reflected in Nagoya Protocol Article 12(1): see this commentary on Article 12, section 2.

56 UNDRIP Article 27. See section 3.3 below.

57 UNDRIP Article 32(2), which refers explicitly to 'particularly in connection with the development, utilization or exploitation of mineral, water or other resources.' We are grateful to Annalisa Savaresi for her inputs on this section.

$5^{8} \quad$ Nagoya Protocol 27th preambular recital.

59 Nagoya Protocol 26th preambular recital.

6o UNDRIP Article 31(1).

61 UNDRIP Article 24(1).

62 UNDRIP Article 20. 
In the light of international human rights standards, it will be necessary to ascertain who are the 'communities concerned' in a specific Party (considering questions of national and international law, as discussed below). UNDRIP recognizes the right to maintain and develop indigenous peoples' political, economic and social systems or institutions, which in the context of the Protocol raises a specific question as to the appropriate community authorities that should be engaged in ABs transactions. ${ }^{63}$ This arguably implies that the Party must actively identify all relevant communities that are entitled to receive benefits, or at least carefully avoid excluding relevant communities rightfully claiming to have a right over the genetic resources at stake from receiving benefits. ${ }^{64}$ The obligation to achieve 'fair and equitable' benefit-sharing not only refers to the relationship between users of genetic resources and the communities holding rights over these resources, but arguably also encompasses notions of inter- or intra-community fairness in distributing benefits. ${ }^{65}$

\section{2 'Established Rights' and Other Qualifications}

International human rights law also indicates how States should interpret the puzzling qualifications in Article 5(2) in good faith so as to protect and progressively realize indigenous and local communities' rights related to genetic resources in light of their applicable international human rights obligations.

This is particularly the case of the qualification that benefit-sharing from the use of genetic resources held by indigenous and local communities is to occur 'in accordance with domestic legislation regarding the established rights of indigenous and local communities' over these genetic resources.

63 UNDRIP Article 20. Note that the individuals holding the traditional knowledge within a certain community may not necessarily be those that are authorised according to the community's customary laws and practices to provide PIC: we are grateful to Nicole Schabus for a useful exchange of ideas on this matter. See this commentary on Article 7, section 3.

64 On the relevance of indigenous peoples' human rights for local communities, see Introduction to this commentary, section 3.2.

65 Rachel Wynberg, "Rhetoric, Realism and Benefit Sharing: Use of Traditional Knowledge of Hoodia Species in the Development of an Appetite Suppressant," Journal of World Intellectual Property 7 (2004): 851, 862; Singh Nijar "An Asian Developing Country's View," op. cit., 262. An example can be found in Peru's Law Introducing a Protection Regime for the Collective Knowledge of Indigenous Peoples Derived from Biological Resources, No. 27811, 2002 Article 10. The same law also makes provision for the sharing of profits arising from the commercialization of collective knowledge of indigenous peoples and local communities that has entered the public domain in the last 20 years. See Singh Nijar “An Asian Developing Country's View," op. cit., 261-262. 
The formulation arguably illustrates concerns that benefit-sharing should follow recognition in domestic legislation of rights of indigenous and local communities over specific genetic resources, ${ }^{66}$ or concerns that questions related to ownership of genetic resources should not be treated in isolation from general property laws that differ significantly from one jurisdiction to another. ${ }^{67}$ In that regard, it should first be noted that in many countries no legal provisions exist determining ownership over genetic resources. ${ }^{68}$ Second, there may be a discrepancy between the customary law of indigenous and local communities recognizing their rights over natural resources and national legislation. International human rights bodies, however, have indicated that indigenous peoples have rights over natural resources even in the absence of recognition in domestic frameworks. ${ }^{69}$

66 Greiber et al., Explanatory Guide, op. cit., 87. For a criticism of this approach, see "Nagoya Protocol on access and benefit sharing: Substantive and procedural injustices relating to indigenous peoples' human rights. Joint submission Grand Council of the Crees (Eeyou Istchee) et al. to the ICNP," СвD, (June 2011), accessed 30 November 2013, <www.cbd .int/abs/doc/protocol/icnp-1/joint-submission-grand-council-and-others-en.pdf>, paragraphs 68-75.

67 We are grateful to Tomme Young for drawing our attention to this point.

68 Свр, "Overview of recent developments at national and regional levels relating to access and benefit-sharing," UNEP/CBD/WG-ABS/5/4. See also СвD Working Group on ABS, "Analysis of existing national, regional and international legal instruments relating to access and benefit-sharing and experience gained in their implementation, including identification of gaps. Note by the Executive Secretary" (10 November 2004) un Doc unep/cbd/wg-Abs/3/2; and Jorge Cabrera Medaglia, Frederic Perron-Welch and Olivier Rukundo, Overview of National and Regional Measures on Access to Genetic Resources and Benefit-Sharing: Challenges and Opportunities in Implementing the Nagoya Protocol (Ottawa: Centre for International Ssustainable Development Law, 2011), accessed 30 November 2013, <http://cisdl.org/biodiversity-biosafety/public/docs/Overview_of_ ABS_Measures_2011.doc >.

69 Human Rights Council, "Report of the Special Rapporteur of indigenous peoples' rights," A/HrC/24/41, paragraphs 9, 12 and 35. The latter paragraph reads: 'It should be recalled that under various sources of international law, indigenous peoples have property, cultural and other rights in relation to their traditional territories, even if those rights are not held under a title deed or other form of official recognition,' emphasis added. See Savaresi, "International Human Rights Law Implications," op. cit., 70; Lenzerini, "Indigenous Peoples' Cultural Rights," op. cit., 137, on the basis of Case of the Mayagna (Sumo) Awas Tingni Community v Nicaragua, Merits, Reparations and Costs, Judgement, Case No. 11,577 (IACtHR, 31 August 2001), (hereinafter, Awas Tingni Community v Nicaragua) 153: 'The Court believes that, in light of article 21 of the Convention, the State has violated the right of the members of the Mayagna Awas Tingni Community to the use and enjoyment of their property, and that it has granted concessions to third parties to utilize the property 
Against this background, the reference to 'established rights,' which can be traced back to the Bonn Guidelines, ${ }^{70}$ may be interpreted in a narrow or broad sense with significant implications for the rights of indigenous and local communities under the Protocol. According to a narrow interpretation, the term 'established' may only refer to situations where a particular community can demonstrate that its right to genetic resources is already affirmed by domestic legislation, agreement or judicial ruling. According to this interpretation, if such rights are not already proved within their national legal order, communities are not entitled to any right to PIC for access to genetic resources in their territories under the Protocol. ${ }^{71}$ Accordingly, the reference to 'established rights' may possibly leave it to the absolute discretion of the Party concerned to determine whether such community rights exist and therefore whether or not to develop domestic measures on sharing benefits with relevant communities. ${ }^{72}$

This interpretation, however, appears overly restrictive and not in harmony with international human rights standards and the Protocol objective. ${ }^{73}$ In that regard, 'established rights' can also include community customary rights. This alternative interpretation has been supported by the UN Permanent Forum on Indigenous Issues, ${ }^{74}$ recalling that a government distinguishing between 'existing' rights as enshrined in domestic law and the customary rights of indigenous peoples was found to be discriminatory by the UN Committee on the

and resources located in an area which could correspond, fully or in part, to the lands which must be delimited, demarcated, and titled.' See further Moiwana Community v. Suriname, 101: 'the proven facts demonstrate that a N'djuka community's connection to its traditional land is of vital spiritual, cultural and material importance.'

70 Bonn Guidelines, paragraph 31 reads: 'Respecting established legal rights of indigenous and local communities associated with the genetic resources being accessed or where traditional knowledge associated with these genetic resources is being accessed, the prior informed consent of indigenous and local communities and the approval and involvement of the holders of traditional knowledge, innovations and practices should be obtained, in accordance with their traditional practices, national access policies and subject to domestic laws,' emphasis added.

See expression of concern in that regard in "Joint submission Grand Council of the Crees (Eeyou Istchee) et al.," 12.

This possible interpretation was identified with concern by Gurdial Singh Nijar, The Nagoya Protocol on Access and Benefit Sharing of Genetic Resources: Analysis and Implementation Options for Developing Countries (South Centre and CEBLAW, 2011), accessed 30 November 2013, <www.southcentre.int/wp-content/uploads/2013/08/ Ev_130201_GNjarl.pdf>, 25-26.

73 See this commentary on Article 1.

74 UNPFII, "Report on the tenth session," E/2011/43-E/C.19/2011/14, paragraph 6. 
Elimination of Racial Discrimination. ${ }^{75}$ The expression 'established rights' can also be interpreted to encompass relevant internationally protected human rights of indigenous and local communities to the lands and natural (including genetic) resources traditionally used by them, ${ }^{76}$ as upheld in international human rights case law. ${ }^{77}$ Interpreting 'established rights' on the basis of relevant international human rights law and in light of community customary laws would thus imply an obligation for Parties to map customary rights at the domestic level, in consultation with the concerned communities, ${ }^{78}$ provide for their legal recognition, and enact domestic measures to ensure benefit-sharing with communities when their customary rights over genetic resources are so ascertained. ${ }^{79}$ The inseparable nature of genetic resources and traditional knowledge for indigenous and local communities, recognized in the Protocol preamble ${ }^{80}$ and largely underpinning the rationale behind this provision, further substantiates the need for a broader interpretation of Article 5(2). As noted below, ${ }^{81}$ the obligation for Parties to enact domestic measures to ensure benefit-sharing for indigenous and local communities in relation to traditional knowledge associated with genetic resources is not conditioned on the existence

75 See CERD, "Concluding observations of the Committee on the Elimination of Racial Discrimination. Guyana" (4 April 2006) CERD/C/GUY/Co/14, 1; and Awas Tingni Community v. Nicaragua, parapgrah 140 (d).

76 Lenzerini, “Indigenous Peoples' Cultural Rights," op. cit., 139-140; and this commentary on Article 5, section 3.

77 For instance, the Inter-American Commission on Human Rights has noted that there is a 'customary international law norm, which affirms the rights of indigenous peoples to their traditional lands': Awas Tingni Communityv. Nicaragua, paragraphs 148-155. See also Endorois Welfare Councilv. Kenya, paragraphs 140(d), 196 and 207. For a discussion on the existence of customary international law in this regard, see Fodella, "Indigenous Peoples, the Environment and International Jurisprudence," op. cit., 360 (fn. 73) and 354-356; Hendrick A. Strydom, "Environment and Indigenous Peoples," in Wolfrum, Max Planck Encyclopedia, op. cit., paragraphs 4-8 and 17-19; Wiessner, "Indigenous Sovereignty", op. cit.; and International Law Association, The Hague Conference Report, op. cit., 48.

78 See fn. 54 above.

79 On global jurisprudence on indigenous peoples' rights to land and natural resources, see sources analysed by Fodella, "Indigenous Peoples, the Environment and International Jurisprudence," op. cit., 349 (fn. 59), 351 and 353 (fn. 11 and 26). On the human right to land as a self-standing right that is part of indigenous peoples' right to property and as a component of the right to food, see also De Schutter, "The Emerging Human Right to Land," op. cit., particularly 310-314.

8o Nagoya Protocol 22nd preambular recital.

81 See section 4 below on Article 5(5). 
of specific rights, but it is rather based on the right to cultural identity ${ }^{82}$ of these communities.

According to the broad interpretation of 'established rights', a human rights-cognizant interpretation of Article 5(2) seems to point to an underlying obligation for Parties to the Protocol to recognize the rights of communities in national legislation, in accordance with their international human rights obligations, taking into account the customary laws of indigenous and local communities ${ }^{83}$ and as a result of good-faith consultation with these communities. ${ }^{84}$ In light of these considerations, the right of communities extends to retaining possession of genetic resources that are decisive for the enjoyment of their rights to safeguard their cultural identity and integrity. ${ }^{85}$ Should the State, however, claim ownership over genetic resources held by communities, specific procedures are to be put in place to ascertain to which degree indigenous peoples' rights are prejudiced, and still ensure benefitsharing for the relevant communities in light of their right to PIC. ${ }^{86}$ As a minimum, therefore, Parties are to ensure respect for indigenous peoples' right to participate in the decision-making and management of any kind of initiative taken by the government concerning their genetic resources, as well as to guarantee a certain degree of legal and administrative autonomy for these communities in the administration of these resources. ${ }^{87}$

Two other qualifications are worth briefly discussing here. First, it should be noted that Article 5(2) only refers to benefit-sharing for the utilization of genetic resources held by communities. Unlike Article 5(1), it does not refer

82 Fodella, "Indigenous Peoples," op. cit., 350, (fn. 4): Human Rights Committee, Kitok v. Sweden, Communication no. 197/1985 (27 July 1988), UN Doc CCPR/C/33/D/197/1985, paragraph 9(2); Human Rights Committee, Lubicon Lake Band v. Canada, Communication no. 167/1984 (26 March 1990), un Doc CCPR/C/38/D/167/1984, paragraph 32(2); General Comment No. 23, paragraphs 3(2) and 7.

83 Nagoya Protocol Article 12(1).

84 See fn. 54 above.

85 Lenzerini, "Indigenous Peoples' Cultural Rights," op. cit., 137, based on Awas Tingni Community v. Nicaragua, paragraph 153; and Moiwana Community v. Suriname, paragraph 101.

86 Lenzerini, "Indigenous Peoples' Cultural Rights," op. cit., 139, based on ILO Convention No. 169 Article 15 and Inter-American Court of Human Rights, Case of the Yakye Axa Indigenous Community v. Paraguay, Merits, Reparations and Costs, Judgment, Case No. 12,313 (IACtHR, 17 June 2005), paragraphs 140-148.

87 Lenzerini, “Indigenous Peoples' Cultural Rights," op. cit., 135, based on Committee on the Elimination of Racial Discrimination, "General Recommendation No. 23: indigenous peoples” (18 August 1997) un Doc A/52/18, paragraph 5. 
explicitly to 'subsequent applications and commercialization'. A strictly literal interpretation that would result in depriving indigenous and local communities from benefit-sharing arising from the subsequent applications and commercialization related to genetic resources held by them should be rejected. Such restrictive reading would unfairly limit the scope of benefits flowing back to indigenous and local communities concerned, which would not serve the Protocol objective of realizing equitable and fair benefit-sharing vis-à-vis these communities. ${ }^{88}$ Furthermore, as Article 5(2) addresses a sub-set of benefit-sharing under Article 5(1), a systemic interpretation would support an understanding of benefit-sharing from subsequent applications and commercialization both for genetic resources held by States and for those held by communities. In practice, it will be particularly significant for Parties to clearly address this point in their domestic ABs frameworks, and for indigenous and local communities representatives to be involved in the development of domestic measures on this point. Second, the qualifier 'as appropriate' leaves discretion as to the type of implementing measures that Parties have to adopt, but not as to whether to adopt measures at all or not. ${ }^{89}$

\section{Benefit-sharing from the Utilization of Traditional Knowledge}

In accordance with Article 5(5), Parties are required to take the appropriate legislative, administrative or policy measures, to ensure that benefits arising from the utilization of traditional knowledge associated with genetic resources are shared in a fair and equitable way with the indigenous and local communities holding such knowledge. In contrast to the obligation included in 5(2), Parties' obligation with regard to traditional knowledge is unencumbered by references to the need for accordance with national law. ${ }^{90}$

Article 5(5) is a new obligation that goes beyond the CBD text. ${ }^{91}$ For the first time in international environmental law, a treaty creates a binding obligation for States to establish measures to reward communities for developing and preserving traditional knowledge associated with genetic resources and for thus contributing to scientific progress for the benefit of the global community. From

\footnotetext{
88 See this commentary on Article 1, section 2.

89 See Introduction to this commentary, section 5 and fn. 227.

9o As observed earlier, the qualifier 'as appropriate' leaves discretion in relation to the type of implementing measures that Parties have to adopt, not as to whether these measures should be adopted at all or not.

91 Compare with CBD Article 15(7).
} 
a broader international law perspective, even if this provision does not employ human rights language, it can be interpreted as implicitly underpinned by a substantive environmental right ${ }^{92}$ for indigenous and local communities to their traditional knowledge associated with genetic resources. This can be seen as an implication deriving from the established international human rights, in their collective dimension, concerning indigenous peoples' self-determination and cultural identity. The Nagoya Protocol, however, goes beyond the letter of international human rights instruments, by encapsulating, in a legally binding provision, a benefit-sharing obligation owed directly to communities that arises specifically from the use of traditional knowledge associated with the genetic resources. In comparison, UNDRIP recognizes more generally the right to maintain, control, protect and develop traditional knowledge, including intellectual property over such traditional knowledge. ${ }^{93}$ In addition, the Protocol identifies not only indigenous peoples, but also local communities ${ }^{94}$ as beneficiaries of such obligation.

As opposed to the rest of Article 5, the obligation is two-fold. On the one hand, it entails the development of national measures to ensure that a benefitsharing obligation arises from the utilization of traditional knowledge at the inter-State level (hence, the provision on inter-State collaboration on compliance elsewhere in the Protocol). ${ }^{95}$ On the other hand, it entails the development of a domestic mechanism for such benefits to be shared internally with the relevant indigenous and local communities.

As regards Parties where an indigenous or local community is located, Article 5(5) obliges governments to put in place conditions that enable indigenous and local communities to engage in ABs-related activities concerning their traditional knowledge associated with genetic resources. At a minimum reading Article 5(5) in conjunction with Article 16(1) and 7 - Parties with indigenous and local communities in their territories must establish domestic ABS measures that articulate how to engage with these communities so as to obtain either their PIC or their prior approval and involvement for access to their traditional knowledge, and how to establish мAт. In this regard, Parties with such communities holding traditional knowledge must also be mindful of

\footnotetext{
92 See parallel discussion in section 3 above.

93 UNDRIP Article 31(1). Note that the ILo Convention No. 169 does not mention benefitsharing in relation to traditional knowledge.

94 For a preliminary discussion on the possible legal arguments on the status of the human rights of local communities, see Introduction to this commentary, section 4.2.

95 See this commentary on Article 16.
} 
their obligations to take into account communities' customary laws, ${ }^{96}$ ensure communities' effective participation ${ }^{97}$ and endeavor to support these communities in ABS transactions, ${ }^{98}$ as well as take into account their capacity needs and priorities as identified by them..$^{99}$

Difficulties may arise in practice in determining which indigenous and local communities are 'holding' traditional knowledge concerned in a specific ABS transaction and should therefore be the 'beneficiaries' of benefit-sharing. ${ }^{100}$ Article 5(5) seems to apply only to situations where the traditional knowledge is actually held by one or more communities. ${ }^{101}$ Read in light of the preamble, it is then up to these communities to identify the rightful holders in that connection, ${ }^{102}$ in light of the diversity of circumstances in which traditional knowledge is held or owned by them. ${ }^{103}$

One particular situation arises in the case of traditional knowledge that has been documented or held in other form by a State entity, ${ }^{104}$ such as in traditional knowledge registries or digital libraries. ${ }^{105}$ Traditional knowledge in such registries could be publicly available or not, depending on who is authorized to

$96 \quad$ Nagoya Protocol Article 12(1). See this commentary on Article 12, section 2.

97 UNDRIP Article 19 and comments by Boyle and Chinkin, Making of International Law, op. cit., 50

98 Nagoya Protocol Article 12(3). See this commentary on Article 12, section 4.

99 Nagoya Protocol Article 22(3). See this commentary on Article 22, section 4.

100 The Inter-American Court of Human Rights found that 'the determination of those beneficiaries must be made in consultation with the Saramaka people, and not unilaterally by the State' and that 'these matters can be discussed and addressed during the consultations and process of reaching agreement on the legislative and administrative measures required to give effect to, inter alia, the benefit sharing requirement.' Saramaka People v. Suriname 2008, paragraphs 25-27.

101 Greiber et al., Explanatory Guide, op. cit., 88.

102 Nagoya Protocol 24th preambular recital. Although general international human rights law may call for States to engage in a complex balancing of competing international human rights in that regard, particularly in the case of variance with international norms against discrimination (based on gender, in light of the Protocol 11th preambular recital). See Introduction to this commentary, section 4.3.

103 Nagoya Protocol 23rd preambular recital.

104 Nagoya Protocol 25th preambular recital.

105 See, for example "Traditional Knowledge Digital Library," Indian Government, accessed 30 November 2013, <www.tkdl.res.in/tkdl/langdefault/common/Home.asp?GL=Eng>; "Traditional Chinese Medicine Patents Database," Chinese Government, accessed 30 November <http://chmp.cnipr.cn/englishversion/help/help.html >. See also discussion in this commentary on Article 7, section 3. 
have access to the registries. ${ }^{106}$ In this case, traditional knowledge may either have not been obtained directly by the relevant communities or may no longer be attributable to them. ${ }^{107}$ While the Protocol negotiators discussed whether to address or not publicly available traditional knowledge, ${ }^{108}$ the Protocol eventually remains silent on this issue. It thus remains to be clarified whether and how the benefit-sharing obligation applies to traditional knowledge that is publicly available. ${ }^{109}$ This may be particularly complicated depending on whether such traditional knowledge is regarded as national heritage and/ or whether it can still be traced back to one or more particular community. Parties would be well advised to clarify in their domestic ABs frameworks this question, ${ }^{110}$ or consider the development of guidance by the Protocol's governing body. ${ }^{111}$

Another difficulty may arise from traditional knowledge shared by different indigenous and local communities within the territory of the same Party, as only some of these communities may wish to grant access and enter into MAT and others may not. Parties are well advised, therefore, to articulate in their domestic ABs frameworks how to engage with indigenous and local communities so that all communities holding relevant knowledge do (or have at least a fair and reasonable opportunity to) receive benefits arising from the utiliza-

106 In India, for instance, the Traditional Knowledge Digital Library (TKDL) is only accessible to the patent offices that have signed a TKDL access agreement, including the European Patent Office, and the patent offices of Australia, Canada, Germany, the UK and the us. See V.K. Gupta “Protecting India's Traditional Knowledge," wIPo Magazine (June 2011), accessed 30 November 2013, <www.wipo.int/wipo_magazine/en/2011/03/article_0002. html >.

107 Singh Nijar, The Nagoya Protocol on ABs: An Analysis, op. cit., 28.

108 See draft article 9(5) in Nagoya Draft, which reads: '[5. Parties shall [encourage][require] the users of [publicly available] traditional knowledge associated with genetic resources [which has been lawfully obtained by that user from a source other than an indigenous and local community] to take reasonable measures to enter into fair and equitable benefit-sharing arrangements with the [rightful] holders of [such] knowledge.]' (brackets in the original).

109 Singh Nijar "An Asian Developing Country's View," op. cit., 259-263; Greiber et al., Explanatory Guide, op. cit., 113.

110 Unless this case is further complicated by the presence of traditional knowledge occurring in transboundary situations, in which case Nagoya Protocol Article 11(2) and possibly Article 10 apply.

111 Nagoya Protocol Article 26(4)(d): see this commentary on Article 26, section 2. Note that the issue of 'publicly known' traditional knowledge is currently being negotiated under WIPO, with regard to issues including disclosure requirements, the creation of digital libraries and the prevention of erroneous patents. See wiPo General Assembly, "Matters concerning the IGC," wo/GA/43/14, Annex B, 5. 
tion of their traditional knowledge associated with genetic resources. ${ }^{112} \mathrm{~A}$ truly inclusive and transparent domestic process of consultation between the government and communities, taking in consideration of communities' customary laws, protocols and procedures, ${ }^{113}$ seems to be a pre-requisite for effectively and fairly addressing these questions. Such process should also allow for consultations within and among communities, with a view to ensuring inter- and intra-community fairness in relation to benefit-sharing. ${ }^{.14}$

\section{$5 \quad$ The Role of Mutually Agreed Terms}

Article 5 reiterates that benefit-sharing deriving from genetic resources (whether held by the State or indigenous or local communities) and from traditional knowledge is to be based on mutually agreed terms. ${ }^{115}$ This is because, as noted above, ${ }^{116}$ the international obligations enshrined in Article 5 will in practice most often lead to sharing benefits obtained from private parties, such as research institutions and biotech companies, utilizing genetic resources and traditional knowledge. MAT, a private-law contract,, ${ }^{117}$ is thus seen in the Protocol's architecture as an effective and easily enforceable way to realize benefit-sharing obligations. ${ }^{118} \mathrm{~A}$ key element in a functioning ABS relationship based on mutual confidence, such a contract is expected to clarify individual parties' specific rights and obligations, restrictions in the use of specific material and/or traditional knowledge throughout the research and development chain, as well as information sharing and monitoring duties.

112 Nagoya Protocol Article 11(2).

113 See this commentary on Article 12, section 2.

114 The Inter-American Court observed that 'in the event that any internal conflict arises between members of the Saramaka community regarding [benefit-sharing], it 'must be resolved by the Saramaka people in accordance with their own traditional customs and norms, not by the State or this Court in this particular case.' Saramaka People v. Suriname 2008), paragraphs 25-27.

115 See final clause of Nagoya Protocol Article 5(1-2) and (5).

116 See section 2 above.

117 This is, to some extent, a simplification for the sake of clarity. As explained in the Introduction to this commentary, section 1.3, parties to and the form of MAT, as well as their relation with PIC, may vary significantly from one jurisdiction to another, and possibly also from one case to another. In some instances, the goverment or its designee negotiates MAT and there is at least one separate negotiation with the specific provider(s): we are grateful to Tomme Young for drawing our attention to this point.

118 As is explicitly foreseen in the last sentence of Nagoya Protocol Article 5(1). 
Article 5(2) is silent on the question whether representatives of indigenous and local communities will be parties to MAT spelling out benefit-sharing arrangements for utilizing genetic resources held by these communities, and who will be the other parties (individual users, or the government who may have established a separate set of MAT with the users). The government could also be acting on behalf of relevant communities in establishing MAT with users. In all events, governments may be expected to strengthen the capacity of indigenous and local communities, ${ }^{119}$ upon their request. Similar observations can be made with regard to MAT spelling out specific benefit-sharing modalities arising from the use of traditional knowledge under Article 5(5). One difference, however, is that States have also a best-endeavor obligation to support the development by indigenous and local communities of minimum requirements for MAT to secure fair and equitable benefit-sharing from the utilization of traditional knowledge. ${ }^{120}$

In any of the cases envisaged in Article 5, one should expect that concrete terms for the implementation of the benefit-sharing obligations of the Protocol will, on the basis of applicable national measures, be set out in MAT, such as the conditions, types, timing, and procedures/mechanisms for distribution of benefits. ${ }^{21}$ Notably, however, the Protocol does not attempt to set any substantive or procedural criteria ${ }^{122}$ for establishing $\mathrm{MAT}^{123} \mathrm{so}$ as to provide for fair and equitable benefit-sharing, but rather leaves any consideration of what is fair and equitable to contractual negotiations. Parties providing genetic resources may consider establishing some substantive rules on the contents of MAT in their domestic ABS frameworks. That being said, it may be difficult for provider countries to rely on their domestic ABS frameworks in a foreign court in that regard, if the determination of what is fair and equitable benefit-sharing is not reflected also under mat. ${ }^{124}$ Perhaps for this reason, the Protocol requires Parties individually and collectively through the Protocol's governing body to

119 Nagoya Protocol Article 22(1) and (5)(j).

120 See commentary on Article 12, section 4. Note, however, that the Protocol only establishes such as obligation in relation to MAT concerning the utilization of traditional knowledge in Article 12(3)(b), but not about MAT concerning genetic resources held by indigenous and local communities.

121 Greiber et al., Explanatory Guide, op. cit., 90.

122 Tvedt, "Beyond Nagoya," op. cit., 161 and 163.

123 Note the reference to 'benefit-sharing' (and the absence of reference to 'fair and equitable') in Nagoya Protocol Article 6(3)(g)(ii): see this commentary of Article 6, section 7.

124 Greiber et al., Explanatory Guide, op. cit., 160-161 and 163. See this commentary on Article 18. 
explore model contractual clauses ${ }^{125}$ and voluntary instruments ${ }^{126}$ as a source of inspiration for fair and equitable benefit-sharing contracts. It also points to awareness-raising ${ }^{127}$ and training activities ${ }^{128}$ to that end. That being said, the Protocol preamble reflects Parties' recognition of the importance of promoting equity and fairness in the negotiations of MAT, ${ }^{129}$ which appears crucial for Parties to effectively and in good faith contribute to the realization of the fair and equitable benefit-sharing objective of the Protocol. ${ }^{130}$

Other provisions of the Protocol, however, do not address this point, but rather contain a list of minimum requirements on the content of MAT to be included in domestic access measures; ${ }^{131}$ envisage that Parties support indigenous and local communities in determining minimum requirements for MAT concerning traditional knowledge, ${ }^{132}$ provide for legal recourse in user countries for ensuring users' compliance with MAT, which can rely on existing rules of private international law; ${ }^{133}$ and encourage including in MAT requirements on information-sharing and reporting on implementation. ${ }^{34}$

\section{Monetary and Non-monetary Benefits}

According to Article 5(4), benefits arising from the utilization of genetic resources and from traditional knowledge concern monetary and non-monetary benefits, including but not limited to those in the Annex to the Protocol. Read together with the Annex, therefore, Article 5(4) provides guidance to Parties developing domestic ABS frameworks and engaging in the establishment of MAT in their consideration of a range of benefits to be shared. It will also guide private providers and users when negotiating MAT.

Non-monetary benefits may be more immediately identifiable and available, given the usually lengthy research and development process and uncertainty related to ultimate commercialization. Non-monetary benefits can also contribute to gradually building the capacity of provider countries in utilizing their

\footnotetext{
125 Nagoya Protocol Article 19.

126 Nagoya Protocol Article 20.

127 Nagoya Protocol Article 21.

128 Nagoya Protocol Article 22(4)(c) and 22(5)(b).

129 Nagoya Protocol 10th preambular recital.

130 See this commentary on Article 1, section 2 and Conclusions to this commentary, section 2.

131 Nagoya Protocol Article 6(3)(g). See this commentary on Article 6, section 6.

132 Nagoya Protocol Article 12(3)(b).

133 See this commentary on Article 18.

134 Nagoya Protocol Article 17(1)(b).
} 
genetic resources. ${ }^{135}$ In that connection, some non-monetary benefits may be seen as having 'high value to the provider and low marginal cost to the user.'136 Certain types of non-monetary benefits may be targeted to support long-term cooperative relations among the parties to the ABs transaction, such as sharing of research and development results, collaboration in scientific research and development, participation in product development, and admittance to ex situ facilities and databases. ${ }^{137}$ This is also the case of capacity building and training. ${ }^{138}$ In addition, non-monetary benefits may be targeted to specifically contribute to conservation efforts, ${ }^{139}$ and/or to the sustainable development at the national and local level, ${ }^{140}$ such as food and livelihoods security benefits, and contributions to the local economy. ${ }^{141}$ These types of benefits, however, may raise concerns about undue interferences of user countries and users into the exercise of provider countries' sovereignty in determining the domestic sharing of benefits. ${ }^{142}$

That being said, monetary benefits may also contribute to long-term collaboration among parties to ABS transactions through joint ventures and joint ownership of relevant IPRs. ${ }^{143}$ It is worth emphasizing that the Annex to the Protocol includes, both in relation to monetary and non-monetary benefits, one of the very few references to IP Rs that can be found in the whole Protocol text. ${ }^{144}$ This may be surprising as IPR-related concerns were prominent throughout the negotiations of the operative text of the Protocol. Eventually, however, the relationship between ABS and IPRS was not addressed in the Protocol..$^{145}$

In addition, monetary benefits may also contribute to conservation efforts (special fees to be paid to trust funds supporting conservation and sustainable use of biodiversity). ${ }^{146}$ Most notably, they also include actual financial benefits

135 Glowka and Normand, "The Nagoya Protocol on Access and Benefit-Sharing," op. cit., 32.

136 We are thankful to Geoff Burton for making this point, which is also reflected in Greiber et al., Explanatory Guide, op. cit., 88.

137 E.g. Nagoya Protocol Annex, 2(a-c) and (e).

138 Nagoya Protocol Annex, 2(d), (g-i), (n) and (j).

139 Nagoya Protocol Annex, 2(k) and (m).

140 Greiber et al., Explanatory Guide, op. cit., 269.

141 Nagoya Protocol Annex, 2(o) and (l).

142 We are grateful to Tomme Young for drawing our attention to this point.

143 Nagoya Protocol Annex, 1(i) and (j).

144 Nagoya Protocol Annex, 1(j) and 2(q), both reading 'joint ownership of relevant intellectual property rights.' The other reference can be found in Article 6(3)(g)(ii) on possible elements of MAT.

145 On this issue, see Introduction to this commentary, section 1.1 and Pavoni, "The Nagoya Protocol and wTo," op. cit., 200-205.

146 Nagoya Protocol Annex, l(f). 
reaching the provider country and relevant communities in the form of access fees, up-front or milestone payments, royalties and license fees. ${ }^{147}$

Finally, it should be noted that while the Annex identifies types of benefits to be shared, it is silent on possible links between specific benefit types and specific ABs transactions. Parties to the Protocol, and subject to possible limitations in national legislation, individual parties to specific ABs transactions, therefore, retain quite some flexibility in tailoring benefit-sharing on a caseby-case basis. Nevertheless, the objective of the Protocol to achieve fairness and equity through benefit-sharing, and to contribute to biodiversity conservation and sustainable use, ${ }^{148}$ should guide Parties in the exercise of their discretion when setting relevant domestic measures and directly participating in the establishment of MAT. When government entities are not directly involved in the establishment of MAT, their good-faith efforts in realizing the objective of the Protocol will rather take the form of proactive encouragement, ${ }^{149}$ and possibly also control and monitoring, ${ }^{150}$ of private parties. In the specific case of benefit-sharing reaching indigenous and local communities, relevant international human rights standards should also be taken into account: caution should be exercised in identifying benefits that are culturally appropriate and endogenously identified, ${ }^{151}$ as certain benefit types or benefit-sharing arrangements can have disruptive effects on the communities' identities and internal governance structures. ${ }^{152}$

147 Nagoya Protocol Annex, 1(a-e).

148 See this commentary on Article 1.

149 As specifically mandated by Nagoya Protocol Article 9 in relation to directing benefits towards conservation and sustainable use: see this commentary on Article 9.

150 In the light of the general notion of due diligence in international law: see discussion in Conclusions to this commentary, section 3.

151 As a result of the interpretation of human rights instruments, such as ILo Convention No. 169, Article 15(2) and Undrip Article 32. See also American Convention on Human Rights (San Jose, 22 November 1969, in force 18 July 1978) 1144 unTs 123, Articles 1(1) and 21 .

$15^{2}$ For example, Munyi and Jonas report how the Hoodia benefit-sharing agreement represents 'a process that has arguably further undermined [communities'] traditional values and knowledge and resource governance system' and 'weakened the San's traditional form of authority,' increasing reliance on 'external expert opinion,' leading to 'largely misunderstood and, at times corrupt new forms of governance,' and exacerbating 'power and information asymmetries in and across San communities,' as well as fostering mistrust. Peter Munyi and Harry Jonas, "Implementing the Nagoya Protocol in Africa: Opportunities and Challenges for African Indigenous Peoples and Local Communities," in Morgera, Buck and Tsioumani, 2010 Nagoya Protocol on Access and Benefit-Sharing in Perspective, op. cit., $217,227$. 